\title{
Geographic Factors for Managing Cruise Ship Destination Port to Attraction Passenger Transfer in the Caribbean Region
}

\author{
John E. Nyberg a, *, Shachak Pe'eri ${ }^{\text {b }}$, Susan L. Slocum ${ }^{\mathrm{c}}$, Matthew Rice ${ }^{\text {a }}$ \\ a Department of Geography and Geoinformation Science, George Mason University, Fairfax, VA 22030, USA; \\ jnyberg@gmu.edu, mrice4@gmu.edu, \\ ${ }^{\mathrm{b}}$ Office of Coast Survey, National Ocean Service, NOAA, Silver Spring, MD 20910, USA; Shachak.Peeri@noaa.gov, \\ c Tourism and Events Management, George Mason University, Fairfax, VA 22030, USA; sslocum@gmu.edu \\ * Corresponding author
}

\begin{abstract}
The Cruise Line industry (CLI) is working on plans to recover from the economic impacts of COVID-19. Along with the expected benefits of a post COVID19 surge in cruise tourism, destination ports have an opportunity to mitigate potential impacts that come with the tourist economy. In this study, we expand on our previous work on four CLI destination sites (two in the Caribbean and two meso-American) to a larger regional study area in the Caribbean Sea and investigate the sustainability of destination marine infrastructure and near port transportation resilience. TwentyEight destinations were analyzed in the study. All the CLI destinations ports in the study are considered mature for cruise tourism and have tourist attractions of interest (including historic, natural, shopping, and other areas with sociocultural authenticity), which can be reached during a one day ship visit. An analysis of the marine traffic and geographic settings provides a more complete picture on key parameters that can potentially impact the commerce and livelihoods of local communities near destination ports. The results of the study also provide potential solutions for mitigating these impacts. As a baseline for fully operational cruise industry in the Caribbean Sea, the 2019 cruise year was analyzed since it was the last full year without impact from COVID-19. This paper offers a wider empirical view of CLI impacts on the Caribbean region once the industry resumes to full capacity following the COVID-19 pandemic, and it presents results and recommendations to build a framework for continued study of CLI sustainability.
\end{abstract}

Keywords: cruise ship tourism, port facility preparedness, Caribbean Sea, nautical charting, hydrography, nautical cartography, port infrastructure

\section{Introduction}

Previous work on Caribbean Sea cruise tourism identifies the impact of international tourism on local cultures where economics are seen as a key issue in tourism management and policy Wood (2000) and Wood (2004). In addition to economics, environmental and cultural impacts are also being considered with particular attention paid to the aspects of near shore CLI transportation. Near-shore challenges between national authorities and the CLI include port facility preparedness and potential stresses on local infrastructure. Destination characteristics, including port infrastructure, port location, and passenger excursions, have been identified and used to quantify the impact of the CLI on established destinations. Both positive and negative characteristics can be used to evaluate the impact on destinations and negotiate terms between the CLI and the local communities at the destinations being visited. An analysis of these near shore challenges can potentially quantify the issues and become part of the negotiation and communication between all parties involved (government, business, and tourists). A positive outcome from the negotiation is the ability to ensure sustainable CLI destinations.
The geographic settings, cultural history, and land transportation infrastructure for each of the 28 ports evaluated is unique (Table 1). The high volume of passengers visiting a destination site, short stays, and strict schedules applied to CLI tourism produces irregular challenges within small geographic areas. Proper preplanning steps that include: 1) negotiations between the CLI and destination government, 2) impact assessments, and 3 ) rules that govern CLI volume, should all be strongly considered before a destination agrees to host CLI tourism. The United Nations World Tourism Organization (UNWTO) encourages optimal use of environmental resources while respecting socio-cultural interests and preserving nature and biodiversity to help ensure the longterm viability for all stakeholders UNEP (2005). Some CLI destinations are in the midst of reversing such agreements, notably Venice, Italy and Key West, Florida. In both of these cases, there has been disagreement between the business community and the people who wish to preserve environmental and cultural resources. As a result, Venice and Key West are banning large cruise ships from sensitive areas. In Venice, the ban from entering Venice Lagoon prevents ships that are heavier than 25,000 
tons, longer than 180 meters, or taller than 35 meters Pianigiani \& Bubola, (2021). The Key West ban, approved by Key West voters, then overturned by the Florida Governor, limited the number of persons disembarking from cruise ships to a total of 1,500 per day, prohibited ships with a capacity of more than 1,300 people from disembarking, and gave priority to cruise lines with the best environmental and health records Safer Cleaner Ships (2021). Such disagreements could have been avoided if early negotiations and regulations were conducted with the destination's environmental sensitivity and cultural preferences in mind.

\begin{tabular}{|c|c|}
\hline Destination & Country \\
\hline Amber Cove & Dominican Republic \\
\hline Basseterre & St. Kitts \& Nevis \\
\hline Belize City & Belize \\
\hline Bridgetown & Barbados \\
\hline Cartagena & Colombia \\
\hline Castries & St. Lucia \\
\hline Costa Maya & Mexico \\
\hline Cozumel & Mexico \\
\hline Fort de France & Martinique \\
\hline George Town & Cayman Islands \\
\hline Grand Turk & Turks and Caicos \\
\hline Havana & Cuba \\
\hline Key West & United States \\
\hline Kralendijk & Bonaire \\
\hline Montego Bay & Jamaica \\
\hline Nassau & Bahamas \\
\hline Oranjestad & Aruba \\
\hline Philipsburg & St. Maarten \\
\hline Port Of Spain & Trinidad \\
\hline Progresso & Mexico \\
\hline Roatán & Honduras \\
\hline Roseau & Dominica \\
\hline San Juan & Puerto Rico \\
\hline Scarborough & Tobago \\
\hline St. Georges & Grenada \\
\hline St. John's & Antigua \& Barbuda \\
\hline St. Thomas & U.S. Virgin Islands \\
\hline Willemstad & Curaçao \\
\hline
\end{tabular}

Table 1. Ports Included in this study - Data from 2019
In this study, new emerging and popular technologies were employed to quantify port infrastructure, port location, and passenger excursions. These methodologies are also being used in modern marine cartography as part of the port facility interface analysis Pe'eri et al. (2014). Satellite derived bathymetry (SDB), vessel traffic information from autonomous identification systems (AIS), and data derived from electronic navigational charts determine the CLI impacts on a given destination's port facility, including potential congestion, sea bottom characteristics, and an estimation of cruise ship capacity Nyberg et al. (2021) Focus areas in the port analysis include efficient and safe passenger debarkation, the port's ability to accommodate growth, and the proximity of the ship's debarkation point to areas of interest for tourists. These factors will help to determine the sustainability of the CLI in a destination's near shore environment and may discover potential stressors including local economic disruption, interference with seafaring cultures, and impact on the marine environment.

In this study the terrestrial side of the destination was also evaluated by mapping the distance, type of travel, and potential interference with local populations between the point of disembarkation and popular tourist attractions. The near-port attraction must be within a distance a passenger can travel during a visit and must be offered as an excursion. When available, a site of cultural significance will be used, such as UNESCO heritage sites. In many cases, the only excursions offered at a destination are popular tourist attractions, such as a city center, a beach, or a general tour of the island. Finally, this study provides comparisons between destinations and the impact that the CLI is having on port infrastructure and its surroundings. Based on the study results, some recommendations will be provided on ways to reduce the negative impacts of the CLI. This will help improve the chances of maintaining cruise destinations in a sustainable manner for an extended period of time.

Cruise ship tourism, excluding the heavy impact of the COVID-19 pandemic, has been steadily increasing in popularity both globally and regionally in the Caribbean over the past 10 years. Impact assessments are strongly recommended in order to help destination governments, many of which are desperate for economic recovery. These assessments will help them understand the long term impacts that high-volume, short-stay, CLI tourists have on (often vulnerable) communities and environments. These tools may further help to shape the choices that tourists are making, potentially favoring cruise operators and destinations that take a responsible approach to managing CLI tourism. This study provides critical information to the framework for marine cartography, and demonstrates important connections between traditional bathymetric and terrestrial mapping and modeling. The port facility and infrastructure joining it to the tourist network serve as the interface between these two cartographic domains. 


\section{Previous Work}

Much of the literature addressing the CLI focuses on the economic aspects of cruise tourism and how business should operate to demonstrate benefits to destinations, while maximizing profit for the CLI. Cost and benefits are evaluated by Dwyer et al. (1998) and Dwyer et al. (2004) while cultural impacts on local destinations are assessed by Wood (2000) and Wood (2004). Several authors explore the economic impact of CLI tourist excursions in and around cruise ports Casado-Diaz et al. (2021), De Grosbois (2015), Fridriksson et al. (2020), and Weaver and Lawton (2017). The CLI's business is strongly represented by organizations like the Cruise Line International Association (CLIA) and the Florida-Caribbean Cruise Association (FCCA) who work to capture metrics on passenger satisfaction and dollars spent by both passenger and crew. Recognizing that business is their primary interest, the FCCA's data is still valuable for determining which destinations are preferable to tourists FCCA (2018), due to the focus on major cruise lines and preferred destinations. The ports in this study were chosen based on the FCCA 2018 report. Studies by Brida \& Aapata-Aguirre are frequently cited and also take advantage of CLIA data. Their body of work takes one of the most comprehensive look at overall CLI sustainability and passenger satisfaction Brida and Zapata-Aguirre (2009) and Brida et al. (2013). A later study by MacNeill \& Wozniak builds on this earlier work and makes a case for the taxation and regulation of the CLI MacNeill and Wozniak (2018).

A study by Klein addresses port maturity and the impact on historic culture from high volume cruise tourism Klein (2011). The study cites the similarities between CLI destinations and their shopping options as an example of deteriorating cultural authenticity. Literature often focus on how to reduce negative impact on cultures and the environment in destinations Johnson (2002), Wood (2000) and Wood (2004) but little is published on complete CLI destination sustainability.

Environmental impacts have been one of the main focuses of published literature around the CLI and its destinations, particularly with regard to cruise ship pollution Johnson (2002) and Bonmati (2021). The research paper presented in this paper will not examine the impact of marine pollution on CLI destinations, but it should be considered as a negative by-product of the CLI on CLI destinations. Cruise ships are required to follow the International Convention for the Prevention of Pollution from Ships (MARPOL 73/78) International Maritime Organization (1973). Though MARPOL provides a framework for international regulation of pollution and waste discharge near coastal areas, it is important to ensure that these regulations are also being adhered to nationally. Similarly, air pollution and the use of low sulphur fuel and air scrubbers International Maritime Organization (1973) is also regulated as part of MARPOL and should be a focus of national-level regulation.

\section{Port Characteristics}

All cruise ports, including those in this study (Table 1) have unique characteristics and geographic factors. Some destinations are able to accommodate ships in very close proximity to their tourist districts or city centers and some must construct long piers that appear to be the beginnings of bridges across the ocean. Satellite imagery was used to analyze the port characteristics. Sentinel $2 b$ imagery was downloaded from USGS' EarthExplorer website. The imagery was used to confirm that both Progreso and Costa Maya, Mexico are port destination examples of facilities extending out into deep water (Figure 1). In the case of Progreso, Mexico, the cruise pier has been growing over the years to reach deeper water in order to accommodate larger ships. The pier has grown from two kilometers to 6.5 kilometers since 1985 NASA (2014). Some destinations are unable to accommodate any direct connection to land, forcing cruise tourists to board tenders in order to reach their landside excursion starting points. This is the case in Belize City and George Town, Cayman Islands, where it is common to see 5 cruise ships anchored offshore while passengers are brought ashore (Figure 2).

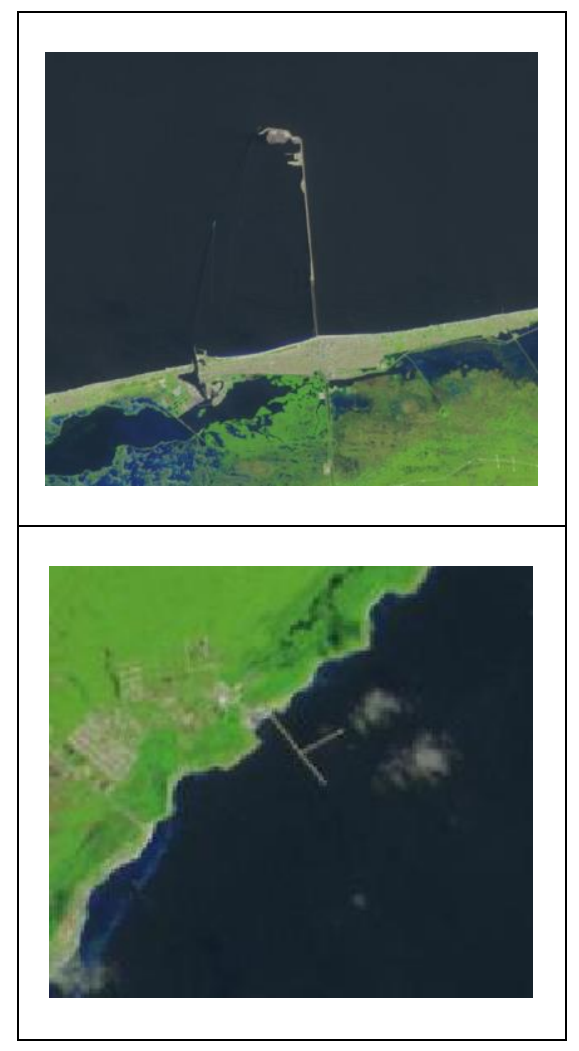

Figure 1. Destination ports with facilities expanding into the water: (left image) Progreso, Mexico and (right image) Costa Maya, Mexico Earth Explorer (2021). 


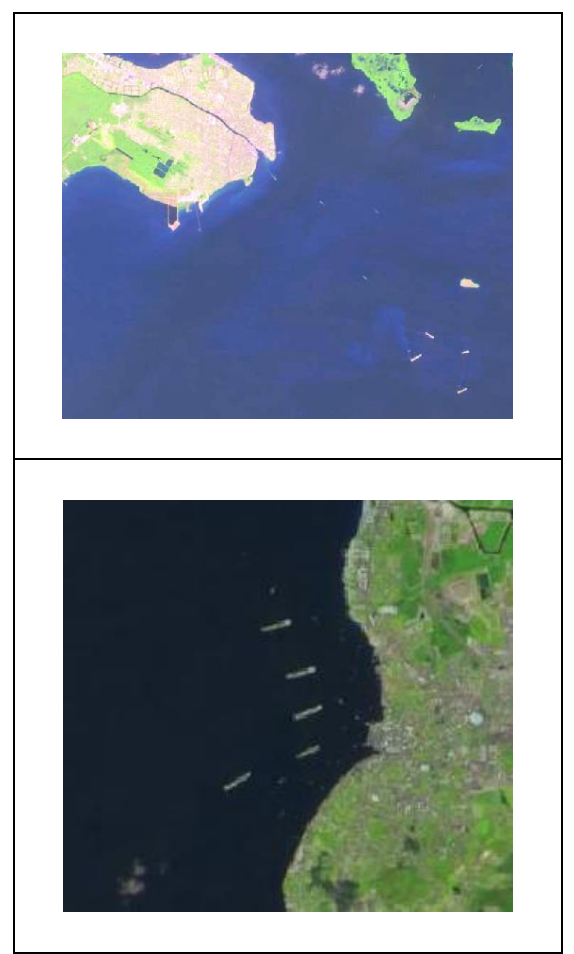

Figure 2. Destination sites with offshore anchorage areas: (left image) Belize City, Belize and (right image) George Town, Cayman Islands Earth Explorer (2021).

Dredging is part of regular port maintenance in most ports around the world. Cruise ports in the Caribbean are no exception. Running tenders from ship to shore (as shown in Figure 2) is not a desirable mode of disembarkation for the CLI because of the added costs in time, fuel, and additional coordination. The result is less time for cruise tourists to spend ashore. However, there are often negative environmental impacts from dredging, which places the local populations at odds with the CLI. In the case of a proposed facility in the Cayman Islands, residents are contesting a new cruise facility that will require dredging 22 acres of George Town Harbor's seabed and may destroy 10 to 15 acres of coral reef Dunning (2021). Some residents are also unconvinced that the new facility will create more opportunity for them, citing the practice of CLI-run excursions that exclude the local economy Nunis (2019). Ports with direct dock access most often require significant dredging. This is very evident in the Google imagery shown for both Grand Turk and Nassau (Figure 3 ). Twenty-three of the ports in this study were identified as requiring some form of dredging in order to maintain or keep up with the growing size of cruise ships.

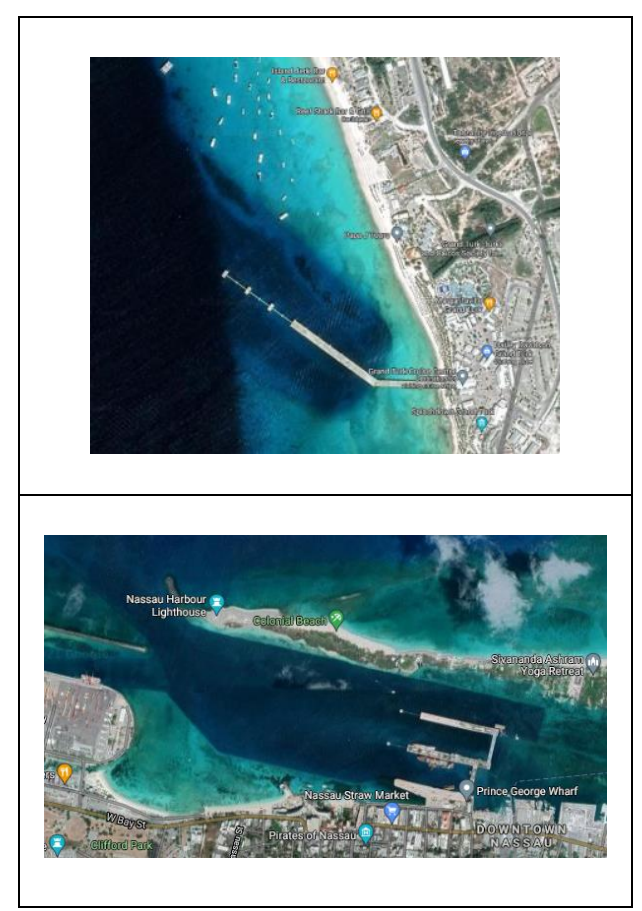

Figure 3. Port destinations that require routine dredging: (left image) Grand Turk, Turks and Caicos and (right image) Nassau, Bahamas Google (2021).

Some destinations have more than one cruise terminal. Forte de France, Martinique and Roatán, Honduras are good examples of distributed cruise pier facilities. In Key West the distributed cruise piers are both owned privately and publicly. In 2020, the citizens of Key West voted to place restrictions on the size and types of cruise ships that call on Key West. The citizen-supported decision was then overturned by the Florida state legislature amid questionable political donations and politicians who do not represent Key West. Currently, the private ownership of one of the cruise piers and its lease agreement with the city of Key West is the one holdout where the new regulations may not be enforceable due to the city's current contract with the pier owner.

Another factor that many destinations contend with is port congestion. Cartagena, Colombia; San Juan, Puerto Rico; and Havana, Cuba (Figure 4); are examples of cities that have grown up around their ports. The physical dimensions of cruise ships (length and width) often interfere with local vessel traffic and impact the regular commerce that takes place in these ports. Chart subsets (Figure 4) illustrate the narrow entrances to these three ports and the location of the cruise terminal in proximity to their commercial ports. In this study, a total of 11 of the ports were found to have a medium to high likelihood of interfering with commercial traffic due to the cruise ship terminal's proximity to container or other shipping traffic. 


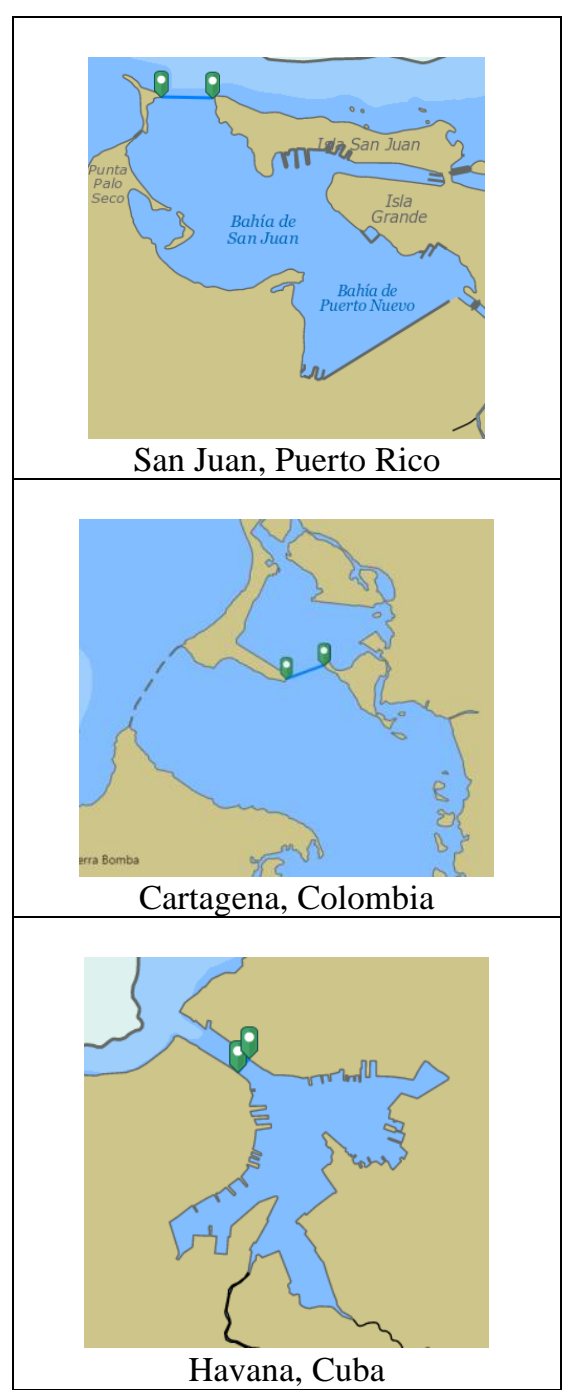

Figure 4. San Juan, Puerto Rico 0.9km; Cartagena, Colombia $0.9 \mathrm{~km}$; Havana, Cuba 0.3km MACHC (2021).

\section{Terrestrial CLI Excursions}

Another indicator in many of the destinations were land excursions, where a primary rank was given to a port destination with a nearby UNESCO heritage site, and secondary rank to either a city center or a popular beach. Although many port destinations that are just cruise stops for particular cruise lines, the CLI does try to accommodate terrestrial excursions in the vicinity of the destination. Amber Cove is an excellent example of a port that was subsidized by a cruise line (Carnival) and primarily accommodates visits to the Carnival owned resort at Amber Cove Albert (2018). However, if a passenger wishes to visit the nearby town of Puerto Plata, offering beaches, colonial city center, and the historic Spanish fortress Fortaleza San Felipe, the excursion requires an additional +10 kilometer journey. The travel times and analysis below (Table 2) show that many of the CLI destinations are not walkable and require a transit through an urban area, indicating that the associated tourism is likely to impact more people than it would if the transit were through a rural area. Even if a destination is walkable directly from the cruise pier, the volume of passengers from cruise ships can cause small destinations like Key West to become congested to a point that local residents may avoid them during busy ship days.

\section{Conclusions}

There are many factors from both the near shore port and terrestrial excursion portions of a cruise ship's visit that impact the sustainable aspects of a destination. The geography of a port and the degree to which it must be altered, by building extensive pier facilities or requiring dredging has the potential to cause serious consequences for the very environments and cultures that attract tourists in the first place BBC (2019). However, destinations that are forced to tender passengers ashore reduce the amount of time that passengers spend at a destination, use extra fuel, add additional small craft traffic to a port area, and ensure that the cruise ships are not connected to shore power during the visit, using fuel and creating air pollution by keeping ship engines running. It would be well advised for local governments to conduct environmental impact assessments before agreeing to any port alterations. Another geographic factor to consider is that of port resource competition. There are several Caribbean cruise ports, including San Juan, Cartagena, and Havana, that share limited geographic areas with commercial shipping interests. All three examples are also larger urban areas that depend on the ports as commercial hubs for their citizens. CLI destinations should require ample negotiation between relevant port authorities and the CLI in areas of regulatory control, port coordination, and port maintenance fees to cover dredging and other maintenance.

Terrestrial physical geography can have profound impacts on the citizens of a CLI destination, from the local commerce in the port, to the commuting patterns and road network in the towns and cities near the port. When CLI tourists leave the ships for excursions, the travel distances to destinations vary greatly (Table 2). Several of the smaller island destinations offer short island tours or visits to local beaches, and about $1 / 3$ of the destinations in the study had attractions that were walkable from the ship. While a walkable destination might indicate that the streets are less likely to be clogged with tourist buses and bus pollution, it doesn't preclude areas near cruise ports from being extremely crowded during ship visits from foot traffic alone. Just under $1 / 2$ of the destinations in this study have popular excursions that are more than 10 kilometers from the disembarkation point. It was assumed that points beyond 10 kilometers would require motorized transportation which in most cases would cause a significant impact on local traffic. Port destination communities are recommended to strongly consider the volume of cruise tourism during the negotiations between the CLI and local governments with clear expectations 


\begin{tabular}{|c|c|c|c|c|c|c|}
\hline Destination & Excursion & UNESCO & Walkable & $\begin{array}{l}+10 \\
\mathrm{Km}\end{array}$ & $\begin{array}{l}\text { Urban } \\
\text { Transit }\end{array}$ & \begin{tabular}{|l|} 
Time \\
(drive)
\end{tabular} \\
\hline Amber Cove & Puerto Plata & $\mathrm{N}$ & $\mathrm{N}$ & $\mathrm{Y}$ & $\mathrm{Y}$ & $\begin{array}{l}18-35 \\
\min \end{array}$ \\
\hline Basseterre & Brimstone Hill & $\mathrm{Y}$ & $\mathrm{N}$ & $\mathrm{Y}$ & $\mathrm{Y}$ & $35 \mathrm{~min}$ \\
\hline Belize City & Tikal National Park & $\mathrm{Y}$ & $\mathrm{N}$ & $\mathrm{Y}$ & $\mathrm{Y}$ & $120 \mathrm{~min}$ \\
\hline Bridgetown & $\begin{array}{l}\text { Historic Bridgetown and its } \\
\text { Garrison }\end{array}$ & $\mathrm{Y}$ & $\mathrm{Y} / \mathrm{N}$ & $\mathrm{N}$ & Y & $\begin{array}{l}10-14 \\
\min \end{array}$ \\
\hline Cartagena & $\begin{array}{l}\text { Ciudad Amurallada - Port, } \\
\text { Fortresses and Group of } \\
\text { Monuments }\end{array}$ & $\mathrm{Y}$ & $\mathrm{N}$ & $\mathrm{N}$ & $\mathrm{Y}$ & $\begin{array}{l}20-40 \\
\min \end{array}$ \\
\hline Castries & Pitons Management Area & $\mathrm{Y}$ & $\mathrm{N}$ & $\mathrm{Y}$ & $\mathrm{Y}$ & $70 \min$ \\
\hline Costa Maya & Chacchoben Myan Ruins & $\mathrm{N}$ & $\mathrm{N}$ & $\mathrm{Y}$ & $\mathrm{N}$ & $55 \mathrm{~min}$ \\
\hline Cozumel & $\begin{array}{l}\text { Many choices from Jeep } \\
\text { excursion to snorkeling }\end{array}$ & $\mathrm{N}$ & $\mathrm{Y} / \mathrm{N}$ & $\mathrm{Y} / \mathrm{N}$ & & \\
\hline Fort de France & Fort de France & $\mathrm{N}$ & $\mathrm{Y}$ & $\mathrm{N}$ & $\mathrm{Y}$ & \\
\hline George Town & $\begin{array}{l}\text { Stingray City offshore boat } \\
\text { trip }\end{array}$ & $\mathrm{N}$ & $\mathrm{N}$ & $\mathrm{Y}$ & $\mathrm{N}$ & \\
\hline Grand Turk & Sun Ray Beach & $\mathrm{N}$ & $\mathrm{N}$ & $\mathrm{N}$ & $\mathrm{N}$ & \\
\hline Havana & $\begin{array}{l}\text { Old Havana and its } \\
\text { Fortification }\end{array}$ & $\mathrm{Y}$ & $\mathrm{Y}$ & $\mathrm{N}$ & $\mathrm{Y}$ & $0 \mathrm{~min}$ \\
\hline Key West & Duval Street & $\mathrm{N}$ & $\mathrm{Y}$ & $\mathrm{N}$ & $\mathrm{Y}$ & $\begin{array}{l}0-10 \\
\min \end{array}$ \\
\hline Kralendijk & Island tour or snorkelling & $\mathrm{N}$ & $\mathrm{N}$ & $\mathrm{N}$ & $\mathrm{Y}$ & $12 \min$ \\
\hline Montego Bay & Dunn's River Falls & $\mathrm{N}$ & $\mathrm{N}$ & $\mathrm{Y}$ & Y & $\begin{array}{l}90-180 \\
\min \end{array}$ \\
\hline Nassau & Atlantis Resort & $\mathrm{N}$ & $\mathrm{N}$ & $\mathrm{N}$ & $\mathrm{Y}$ & $10 \mathrm{~min}$ \\
\hline Oranjestad & Island Tour Very small island & $\mathrm{N}$ & & & & \\
\hline Philipsburg & Tourist Zone Philipsburg & $\mathrm{N}$ & $\mathrm{Y}$ & $\mathrm{N}$ & $\mathrm{Y}$ & \\
\hline Port Of Spain & Maracas Beach & $\mathrm{N}$ & $\mathrm{N}$ & $\mathrm{Y}$ & $\mathrm{Y}$ & $\begin{array}{l}35-50 \\
\min \end{array}$ \\
\hline Progresso & Chichenitza & $\mathrm{Y}$ & $\mathrm{N}$ & $\mathrm{Y}$ & $\mathrm{Y}$ & $\begin{array}{l}170- \\
201 \mathrm{~min}\end{array}$ \\
\hline Roatán & Small island & $\mathrm{N}$ & $\mathrm{Y} / \mathrm{N}$ & $\mathrm{N}$ & & \\
\hline Roseau & $\begin{array}{l}\text { Morne Trois Pitons National } \\
\text { Park }\end{array}$ & $\mathrm{Y}$ & $\mathrm{N}$ & $\mathrm{Y}$ & $\mathrm{Y}$ & $18 \mathrm{~min}$ \\
\hline San Juan & La Fortaleza and San Juan & $\mathrm{Y}$ & $\mathrm{Y} / \mathrm{N}$ & $\mathrm{N}$ & $\mathrm{Y}$ & $10 \mathrm{~min}$ \\
\hline Scarborough & Island tour & $\mathrm{N}$ & $\mathrm{Y} / \mathrm{N}$ & $\mathrm{N}$ & & \\
\hline St. Georges & Concord Waterfall & $\mathrm{N}$ & $\mathrm{N}$ & $\mathrm{Y}$ & $\mathrm{Y}$ & $33 \min$ \\
\hline St. John's & Nelson's Dockyard & $\mathrm{Y}$ & $\mathrm{N}$ & $\mathrm{Y}$ & $\mathrm{Y}$ & $\begin{array}{l}35-45 \\
\min \end{array}$ \\
\hline St. Thomas & Magens Bay & $\mathrm{N}$ & $\mathrm{N}$ & $\mathrm{N}$ & $\mathrm{Y}$ & $\begin{array}{l}18-22 \\
\min \end{array}$ \\
\hline Willemstad & Small island - Many choices & $\mathrm{N}$ & $\mathrm{Y}$ & $\mathrm{N}$ & & 0 \\
\hline
\end{tabular}

Table 2. Travel analysis completed using origin-destination routing with Google Maps with a 9AM weekday departure from cruise port to destination, Google (2021) 
(through port contracts or regulations) on items, such as the number of passengers allowed to disembark at a given time. The threshold number of allowable visitor should be considered, based on the types of excursions offered, the size of the destination, and the infrastructure to support the travel from the port to the excursion. An impact assessment should be completed before these negotiation commence, to provide a useful context on the environmental sustainability of CLI operations.

UNESCO heritages sites are examples of attractions that already follow some best management practices. UNESCO has operational guidelines that discuss the monitoring of heritage sites and the possibility of being removed from the heritage list if evidence emerges of damage or loss to the characteristics that put site on the list UNESCO (2019). Sites that are on the heritage list may also receive site management assistance and financial assistance from UNESCO. Recognizing that not every site has a UNESCO site, and that many destinations have multiple excursions, it is recommended that CLI destinations implement management practices that monitor the volume of visitors and their impacts on all public attractions. This may include limiting the number of visitors or controlling where tourists are allowed, depending on the sensitivity of an attraction. For instance, a historic city center may be able to accommodate a higher tourist volume than a cultural site that has been identified as environmentally sensitive. The near shore port and terrestrial excursion portions of a cruise ship's visit vary greatly between destinations. The levels of sensitivity on environment, culture, and economy are not the same for any destination, but with the proper pre-planning, including negotiations between the CLI and destination government, the proper impact assessments, and rules that govern CLI volume, adverse impacts can be greatly reduced.

\section{References}

Albert, C. (2018, March 20). 20 March 2018; Amber Cove, Dominican Republic. Retrieved from Captain Albert's Blog: https://www.captainalbert.com/20-march-2018amber-cove-dominican-republic/

Bonmati, D.S. Sweatshop on the Highseas: Chapter 3: From Cruise Industry Investigations to Top Executives, Univision Noticias and Columbia Journalism School Online Publication. 2021. Available online: http://huelladigital.univisionnoticias.com/ crucerosvacaciones-en-aguas-de-nadie/trabajo/indexlang=en.html (accessed on 25 January 2021).

Brida, J.G.; Zapata-Aguirre, S. Cruise tourism: Economic, socio-cultural and environmental impacts. Int. J. Leis. Tour. Mark. 2009, 1, 205-226.
Brida, J.G.; Pulina, M.; Riaño, E.; Aguirre, S.Z. Cruise Passengers in a Homeport: A Market Analysis. Tour. Geogr. 2013, 15, 68-87.

Casado-Díaz, A.; Navarro-Ruiz, S.; Nicolau, J.; IvarsBaidal, J. Expanding our understanding of cruise visitors' expenditure at destinations: The role of spatial patterns, onshore visit choice and cruise category. Tour. Manag. 2021, 83, 104199.

De Grosbois, D. Corporate social responsibility reporting in the cruise tourism industry: A performance evaluation using a new institutional theory based model. J. Sustain. Tour. 2015, 24, 1-25.

Dunning, K. H. (2021, May 28). As Tourism Returns, We Can't Allow Cruise Companies to Destroy Coral Reefs for Profit. Retrieved from The Revelator: https://therevelator.org/cruise-companies-coral-reefs/

Dwyer, L.; Peter Forsyth, F. Economic significance of cruise tourism. Ann. Tour. Res. 1998, 25, 393-415.

Dwyer, L.; Douglas, N.; Livaic, Z. Estimating the economic contribution of a cruise ship visit. Tour. Mar. Environ. 2004, 1, 5-16.

Earth Explorer. (July 24, 2021). Belize City, Belize; Costa Maya, Mexico; George Town, Cayman Islands and Progreso, Mexico. Retrieved from https://earthexplorer.usgs.gov/

Florida-Caribbean Cruise Association. Economic Contribution of Cruise Tourism to the Destination Economies: A Survey-Based Analysis of the Impacts of Passenger, Crew and Cruise Line Spending. Business Research \& Economic Advisors (BREA) Report; BREA: Phillipsburg, NJ, USA, 2018.

Fridriksson, J.; Wise, N.; Scott, P. Iceland's bourgeoning cruise industry: An economic opportunity or a local threat? Local Econ. J. Local Econ. Policy Unit 2020, 35, 143-154.

Google. (2021, August 6). Google Maps. Retrieved from Google: https://www.google.com/maps/

Google. (July 24, 2021). Costa Maya, Mexico. Retrieved from https://www.google.com/maps/place/ Costa+Maya+Port+Mexico/@ $18.7312655,87.6919771,1202 \mathrm{~m} /$ data $=! 3 \mathrm{~m} 1 ! 1 \mathrm{e} 3 ! 4 \mathrm{~m}$

$5 ! 3 \mathrm{~m} 4$ ! 1s0x8f5b289b59e8babd:0x520a7ef29a75ede $2 ! 8 \mathrm{~m} 2 ! 3 \mathrm{~d} 18.7336126 ! 4 \mathrm{~d}-87.6945306$ 
Google. (July 24, 2021). Grand Turk, Turks and Caicos. Retrieved from https://www.google.com/maps/place/ Grand+Turk /@ 21.4488934,71.1842413,9451m/ data $=! 3 \mathrm{~m} 1 ! 1 \mathrm{e} 3$ ! $4 \mathrm{~m} 5 ! 3 \mathrm{~m} 4$ ! $1 \mathrm{~s} 0 \times 8 \mathrm{eb} 2 \mathrm{~d} 454094 \mathrm{df} 585$ : 0xcb03d9c378c4644f! $8 \mathrm{~m} 2$ !3d21.4674584!4d71.1389101

Google. (July 24, 2021). Nassau, Bahamas Retrieved from https://www.google.com/maps/place/Nassau,+ The+Bahamas/@25.0800503,$77.3520283,3867 \mathrm{~m} /$ data $=! 3 \mathrm{~m} 1 ! 1 \mathrm{e} 3 ! 4 \mathrm{~m} 5 ! 3 \mathrm{~m} 4$ ! 1s0x892f7c99b981dbc9:0x2aef01d3485e50d2!8m $2 ! 3 \mathrm{~d} 25.0443312 ! 4 \mathrm{~d}-77.3503609$

International Maritime Organization. Proceedings of the Final Act of the International Conference on Marine Pollution, London, UK, 8 October-2 November 1973; p. $166 . \quad$ Available online: https://www.imo.org/en/KnowledgeCentre/

ConferencesMeetings/Pages/Marpol.aspx (accessed on 23 January 2021).

Johnson, D. Environmentally sustainable cruise tourism: A reality check. Mar. Policy 2002, 26, 261-270.

Klein, R.A. Responsible Cruise Tourism: Issues of Cruise Tourism and Sustainability. J. Hosp. Tour. Manag. 2011, 18, 107-116.

MACHC. (2021, August 6). Meso-American and Caribbean Sea Hydrographic Commission. Retrieved from MACHC ENC Viewer: https://www.ihomachc.org/MACHC-ENCOnline/

MacNeill, T.;Wozniak, D. The economic, social, and environmental impacts of cruise tourism. Tour. Manag. 2018, 66, 387-404.

NASA. (2014, November 5). Progreso's Prolonged Pier. Retrieved from NASA Explorer Earth Observatory: https://earthobservatory.nasa.gov/images/85004/ progresos-prolonged-pier

Nunis, V. (2019, December 4). Coral dredging: 'It's going to cause irreversible damage'. Retrieved from BBC News: https://www.bbc.com/news/business-50647625
Nyberg, J.E.; Pe'eri, S.; Slocum, S.L.; Rice, M.; Komwa, M.; Sun, D. Planning and Preparation for Cruising Infrastructure: Cuba as a Case Study. Sustainability 2021, 13, 2951. https://doi.org/10.3390/su13052951

Pe'eri, S.; Parrish, C.; Azuike, C.; Alexander, L.; Armstrong, A. Satellite Remote Sensing as a Reconnaissance Tool for Assessing Nautical Chart Adequacy and Completeness. Marine Geodesy, 2014; Volume 37(3), pp. 293-314.

Pianigiani, G., \& Bubola, E. (2021, July 13). Italy's Government to Ban Cruise Ships from Venice. Retrieved from The New York Times: https://www.nytimes.com/2021/07/13/world/europe/ venice-italy-cruise-ship-ban.html

Safer Cleaner Ships. (2021, August 6). Ballot Language. Retrieved from Safer Cleaner Ships: https://www.safercleanerships.com/ballot-language

UNESCO. (2019). Operational Guidelines for the Implementation of the World Heritage Convention. United Nations Educational, Scientific and Cultural Organization, Intergovernmental Committee for the Protection of the World Cultural and Naturial Heritage. Paris: WORLD HERITAGE CENTRE.

United Nations Environment Programme (UNEP); World Tourism Organization (WTO). Making Tourism More Sustainable-A Guide for Policy Makers, UNEP and WTO Report; UNEP: Paris, France; WTO: Madrid, Spain, 2005.Weaver, D.B.; Lawton, L.J. The cruise shorescape as contested tourism space: Evidence from the warm-water pleasure periphery. Tour. Manag. Perspect. 2017, 24, 117-125.

Wood, R. Caribbean cruise tourism: Globalization at sea. Ann. Tour. Res. 2000, 27, 345-370.

Wood, R. Tourism and Transport: Issues and Agenda for the New Millennium: Chapter 10-Cruise Ships: Deterritorialized Destinations, Advances in Tourism Research; Les Lumsdon, L., Page, S., Eds.; Elsevier Ltd.: Amsterdam, The Netherlands, 2004; pp. 133-145. 